\title{
SURGICAL MANAGEMENT OF LIP CANCER: A 5 YEAR EXPERIENCE
}

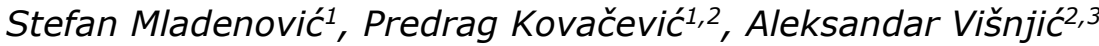

\begin{abstract}
Lip cancer is a common malignancy of the oral cavity as it accounts for $25 \%$ of them and contributes $\sim 12 \%$ to all tumors of the head and neck region. The most frequent lip carcinomas are squamous cell carcinoma (SCC), basal cell carcinoma (BCC), and basosquamous carcinoma (BSC). The aim of this study was to describe clinical characteristics of tumors, surgical technique, and outcomes after lip cancer surgery performed at the University Clinical Center Niš. We conducted a single institution retrospective study including patients who consecutively underwent surgery for carcinoma of the lip at the Clinic of Plastic and Reconstructive Surgery, Clinical Center Niš, in the 5-year period. A total of 32 patients with lip cancer were included in the study. Nineteen (59\%) patients were male and $13(41 \%)$ were female. There were 20 cases of SCC, 11 with BCC and one with BSC. The mean patient age was 73.44 (SD 9.95) at the time of primary examination. Tumors were excised with a minimum surgical margin of $5 \mathrm{~mm}$. Surgical treatment depended on the size of the tumor and its localization. Different surgical techniques were used for reconstructions of the lip defects after tumor removal. Thirty one percent of patients had postoperative complications., There was no recurrence of tumors or tumor related deaths during the follow-up of patients. In patients who had a wider resection of tissue and a more complex reconstruction technique performed, the possibility of occurrence of early postoperative complications is greater.
\end{abstract} Acta Medica Medianae 2020;59(3):68-72.

Key words: lip cancer, surgical treatment, reconstruction, complications

${ }^{1}$ Clinic for Plastic and Reconstructive Surgery, Clinical Center Niš, Serbia

${ }^{2}$ University of Niš, Faculty of Medicine, Niš, Serbia

${ }^{3}$ Institute of Public Health Niš, Niš, Serbia

Contact: Stefan Mladenović

48. Dr. Zoran Djindjić Blvd., 18000 Niš, Serbia

E-mail: fahste1990@yahoo.com

\section{Introduction}

Lip cancer is a common malignancy of the oral cavity as it accounts for $25 \%$ of them and contributes $\sim 12 \%$ to all tumors of the head and neck region (1). The most frequent lip carcinomas are squamous cell carcinoma (SCC), basal cell carcinoma (BCC), and basosquamous carcinoma (BSC), but Merkel cell carcinomas, melanomas, malignant adnexal tumors, and dermatofibrosarcoma protuberans have also been reported (2). BCC generally occur in the upper lip and do not usually present lymph node metastases $(2,3,4)$. Compared to BCC and BSC, SCC is associated with a significantly increased risk of metastasis, and SCC of the lower lip, ear, and temple seems to be associated with the highest risk of metastasis compared to other locations (5-8).

Surgery is the treatment of choice for most of the tumors of the lip. Surgical resection requires a full-thickness resection of the skin, muscle and underlying mucosa to allow a safe surgical margin. A lot of reconstruction methods after tumor removal have been reported, however, the reconstruction of lip defect remains a challenge (9).

\section{The aim}

The aim of this study was to describe clinical characteristics of tumors, surgical technique, and outcomes after lip cancer surgery performed at the University Clinical Center Niš.

\section{Patients and methods}

We conducted a single institution retrospective study including patients who consecutively underwent surgery for carcinoma of the lip at the Clinic for Plastic and Reconstructive Surgery, Clinical Center Niš, in the 5-year period July 2011 to June 2016. In our region, invasive cancers of the lips are routinely referred to our department for surgical treatment. Medical histories and a clinical records database of the Clinic for Plastic and Reconstructive 
Surgery were used as the sources of data for this study. In addition to regular demographic data (gender and age) all available information was collected regarding: macroscopic features of the primary lesions, location of lesion on the lip, type of surgical treatment, postoperative treatment, pathologic outcome and follow-up.

Analysis of the data was performed using the statistical package software SPSS 13.0 (SPSS Inc., Chicago, IL, USA).

\section{Results}

A total of 32 patients with lip cancer were included in the study. Nineteen (59\%) patients were male and $13(41 \%)$ were female. There were 20 cases of SCC, 11 with BCC and one with BSC (Table 1 ). The mean age of all patients was 73.44 years (SD 9.95) at the time of primary examination. Mean age for SCC was 76.90 years (SD 7.00) and for BCC was 66.45 years (SD 11.41).

Chi-square test of independence (whit Yates's correction for continuity), calculated to compare the relationship between gender and type of tumor, did not show statistically significant relationship (BCC and SCC), $\chi^{2}(1, \mathrm{n}=31)=0.910 ; \mathrm{p}=0.34$.

Independent samples t-test did not show a significant age difference between women ( $\mathrm{M}=$ 72.42, $\mathrm{SD}=10.01)$ and men $(\mathrm{M}=73.68, \mathrm{SD}=$ 10.26); $\mathrm{t}(29)=-0.340, \mathrm{p}=0.73$.

Independent samples t-test showed a significant age difference between BCC and SCC type ( $M$ $=66.45, \mathrm{SD}=11.41)$ and SCC type $(M=76.90, \mathrm{SD}$ $=7.00) ; \mathrm{t}(29)=-3.170, \mathrm{p}=0.04$.

Forty one percent of patients had a tumor less than $10 \mathrm{~mm}$ in diameter. Twelve patients (37\%) had a tumor size between 11 and $20 \mathrm{~mm}$. Six patients $(19 \%)$ had a tumor size between 21 and $40 \mathrm{~mm}$. Only one patient had a tumor larger than $40 \mathrm{~mm}$. Seventy five percent of the SCCs were located on the lower lip. Five percent of the SCCS were located at the commissures. Contrariwise, 64\% of BCCs were located on the upper lip. Nine percent of the BCCs were located at the commissure (Table 2).

Table 1. Patients and tumor distribution, $n=32$

\begin{tabular}{|ccccc|}
\hline Gender & SCC, $\mathrm{n}(\%)$ & BSC, n (\%) & BCC, n (\%) & Total, n (\%) \\
\hline \hline female & $9(45)$ & 1 & $3(27)$ & $13(41)$ \\
male & $11(55)$ & 0 & $8(73)$ & $19(59)$ \\
\hline Total, n (\%) & $20(100)$ & $1(100)$ & $11(100)$ & $32(100)$ \\
\hline
\end{tabular}

Table 2. Tumor size and tumor localization, $n=32$

\begin{tabular}{|c|c|c|c|c|}
\hline & SCC, n (\%) & BSC, n (\%) & $\mathrm{BCC}, \mathrm{n}(\%)$ & Total, n (\%) \\
\hline \multicolumn{5}{|l|}{ Tumor size } \\
\hline $0-10$ & $8(40)$ & 0 & $5(46)$ & $13(41)$ \\
\hline $11-20$ & $8(40)$ & 0 & $4(36)$ & $12(37)$ \\
\hline $21-40$ & $3(15)$ & $1(100)$ & $2(18)$ & $6(19)$ \\
\hline$>40 \mathrm{~mm}$ & $1(5)$ & 0 & 0 & $1(3)$ \\
\hline \multicolumn{5}{|c|}{ Tumor localization I } \\
\hline Upper lip & $4(20)$ & 0 & $7(64)$ & $11(35)$ \\
\hline Lower lip & $15(75)$ & $1(100)$ & $3(27)$ & $19(59)$ \\
\hline Commissure & $1(5)$ & 0 & $1(9)$ & $2(6)$ \\
\hline \multicolumn{5}{|c|}{ Tumor localization II } \\
\hline Skin & $1(5)$ & 0 & $2(18)$ & $3(9)$ \\
\hline Vermilion & $14(70)$ & 0 & $1(9)$ & $15(47)$ \\
\hline Both & $5(25)$ & $1(100)$ & $8(73)$ & $14(44)$ \\
\hline Total, n (\%) & $20(100)$ & $1(100)$ & $11(100)$ & $32(100)$ \\
\hline
\end{tabular}


Tumors were excised with a minimum surgical margin of $5 \mathrm{~mm}$ or more. Surgical treatment depended on the size of the tumor and its localization. Tumors were most often removed with full thickness excision (94\%) including the oral mucosa. Two excisions included only the skin. Four patients did not have a clean surgical margin on the final histopathology after the primary excision.

Fifty percent of all patients were operated on in general anesthesia. Nine patients (28\%) were operated on in a local anesthesia and 7 patients $(22 \%)$ were treated in local anesthesia with sedation.
Different surgical techniques were used for reconstructions of the lip defects after tumor removal. The most used technique for reconstruction was Wedge or "W" shaped excision with direct closure $(47 \%)$. Karapandzic flap (Figure 1) was used in 10 cases $(31 \%)$, perialar crescentic melolabial advancement flap (Webster) was used in 3 patients (9\%) and 2 patients $(6 \%)$ underwent reconstructions using the Bernard-Burow advancement flap. In one patient the Pectoralis major musculocutaneous flap was performed for reconstruction.

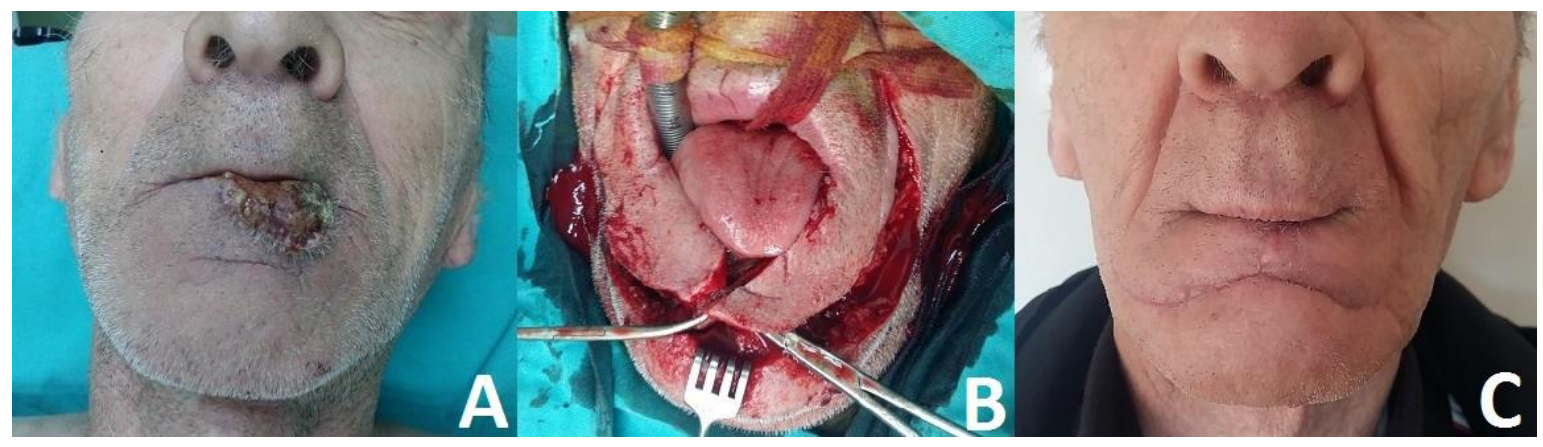

Figure 1. Male patient (79 years old) with SCC of the lower lip. Surgical defect was repaired with Karapandžić flap:
A) preoperative view;
B) intraoperative view;
C) postoperative view after 6 months

Thirty one percent of patients had postoperative complications. Eighteen percent of all patients had postoperative infection. Three patients (9\%) had dehiscence of the wound. Only one patient has late complications in the form of microstomia. Other patients had acceptable functional and aesthetic results.

Median follow-up time of the patients was 12 months ( $\min 3, \max 24)$. A difference in patient follow-up time occurred because some patients did not show up at planned control visits after surgery. During the follow-up of patients there was no recurrence of tumors or tumor related deaths.

\section{Discussion}

In this article we provided information about lip cancer and described the surgical outcome of a series of 32 patients who underwent surgery for lip cancer and were followed over a 5-year period. The most frequently localization of lip cancer was found on the lower lip, in 59\% of the subjects. Also, other authors highlighted same results; Salan A.I. et al. showed that most of the tumors were found in the lower lip (10).
The SCC is most commonly located on the lower lip and the BCC is more common on the upper lip which is similar to reports of other authors $(1,2$, $11)$. We did not find a statistically significant association between gender and tumor type ( $p=0.34$ ) which corresponds to results of a recent study by Queen D. et al. (12). In our study only $15 \%$ of all patients were under the age of 60 and all of them had BCC on final histopathology. The mean age of patients was 73 which is in line with the analysis of other authors $(13,14,15)$. The proportion of male and female patients in our sample corresponds to the data of other authors $(1,13,16,17)$.

The unexpected discovery of our study is a large number of early postoperative complications. Kristiensen et al. (18) also reported high frequency of early postoperative wound healing problems which they associated with defect sizes above 20 $\mathrm{mm}$ and full thickness excisions. The wider resection margins and the use of full thickness excision require more complex reconstructions and potentially higher risk of complications.

In most international researches, follow-up was about 5 years $(1,13,19)$ but some authors (18) also reported problems with follow-up similar to the ones found in our research. Short follow-up led 
to the fact that in our study there were no patients with recurrence or deaths caused by disease progression.

\section{Conclusion}

We found that a wider resection of tissue and more complex reconstruction techniques that were performed on the patients lead to a higher risk of early postoperative complications. Also, we found no recurrence or tumor related deaths during the follow-up period.

\section{References}

1. Maruccia M, Onesti MG, Parisi P, Cigna E, Troccola A, Scuderi N. Lip cancer: a 10-year retrospective epidemiological study. Anticancer Res 2012;32(4):1543-6. [PubMed]

2. Kerawala $C$, Roques $T$, Jeannon JP, Bisase B. Oral cavity and lip cancer: United Kingdom National Multidisciplinary Guidelines. J LaryngolOtol 2016;130 (Suppl 2):S83-S89. [CrossRef][PubMed]

3. Biasoli ER, Bonetti Valente V, Mantovan B, Urbano Collado F, Neto SC, Marcal Mazza Sundefeld ML, et al. Lip cancer: a clinicopathological study and treatment outcomes in a 25-year experience. J Oral Maxillofac Sur 2016;74(7):1360-7. [CrossRef] [PubMed]

4. Khuder SA. Etiologic clues to lip cancer from epidemiologic studies on farmers. Scand J Work Environ Health 1999;25:125-30. [CrossRef][PubMed]

5. Zitsch RP, Lee BW, Smith RB. Cervical lymph node metastases and squamous cell carcinoma of the lip. Head Neck 1999;21:447-53. [CrossRef][PubMed]

6. Takeda A, Akimoto M, Nemoto M, Kounoike N, Uchinuma E. Preoperative risk factors of lymph node metastasis in cutaneous squamous cell carcinoma. J Plast Surg Hand Surg 2013;47:204-8.

[CrossRef][PubMed]

7. Brantsch KD, Meisner C, Schonfisch B, Trilling B, Wehner-Caroli J, Rocken M, et al. Analysis of risk factors determining prognosis of cutaneous squamous-cell carcinoma: a prospective study. Lancet Oncol 2008;9:713-20. [CrossRef][PubMed]

8. Schmults CD, Karia PS, Carter JB, Han J, Qureshi AA. Factors predictive of recurrence and death from cutaneous squamous cell carcinoma: a 10- year, singleinstitution cohort study. JAMA Dermatol 2013; 149: 541-7. [CrossRef][PubMed]

9. Coppit GL, Lin DT, Burkey BB. Current concepts in lip reconstruction. Curr Opin Otolaryngol Head Neck Surg 2004;12:281-7. [CrossRef][PubMed]

10. Salan AI, Camen A, Ciuca A, Patru A, Sciecriu M, Popescu SM, et al. Epidemiological Aspects in Lip Tumors in Oltenia Region of Romania During 20122016. Curr Health Sci J 2018;44(1):39-47. [CrossRef][PubMed]

11. Hasson O. Squamous cell carcinoma of the lower lip. J Oral Maxillofac Surg 2008; 66:1259-62.

[CrossRef][PubMed]
12. Queen D, Knackstedt T, Polacco MA, Collins LK, Lee K, Samie FH. Characteristics of Nonmelanoma Skin Cancers of the Cutaneous Perioral and Vermilion Lip Treated by Mohs Micrographic Surgery. J Eur Acad Dermatol Venereol 2019;33(2):305-311. [CrossRef][PubMed]

13. Vukadinovic $M$, Jezdic $Z$, Petrovic $M$, Medenica $L j$, Lens M. Surgical management of squamous cell carcinoma of the lip: analysis of a 10-year experience in 223 patients. J Oral Maxillofac Surg 2007;65:675-9. [CrossRef][PubMed]

14. Blomgren I, Blomqvist G, Lauritzen C, Lilja J, Peterson $L E$, Holmstrom $H$. The step technique for the reconstruction of lower lip defects after cancer resection. A follow-up study of 165 cases. Scand J Plast Reconstr Surg Hand Surg 1988;22:103-11.

[CrossRef][PubMed]

15. Stratigos A, Garbe C, Lebbe C, Malvehy J, del Marmol $\mathrm{V}$, Pehamberger $\mathrm{H}$, et al. Diagnosis and treatment of invasive squamous cell carcinoma of the skin: European consensus-based interdisciplinary guideline. Eur J Cancer 2015;51:1989-2007. [CrossRef][PubMed]

16. Salgarelli AC, Sartorelli F, Cangiano A, Pagani R, Collini M. Surgical treatment of lip cancer: our experience with 106 cases. J Oral Maxillofac Surg 2009;67:840-5. [CrossRef][PubMed]

17. Rena W, Lia Y, Liua C, Qianga C, Zhang L, Gaoa L, et al. Surgical management of Squamous Cell Carcinoma of the lower lip: An experience of 109 cases. Med Oral Patol Oral Cir Bucal 2014;19(4):e398-402. [CrossRef][PubMed]

18. Kristensen $R$, Andersen $P$, Lock-Andersen J. Lip carcinoma: Clinical presentation, surgical treatment, and outcome: a series of 108 cases from Denmark. J Plast Surg Hand Surg 2017;51(5):342-7. [CrossRef][PubMed]

19. de Visscher JG, van den Elsaker K, Grond AJ, van der Wal JE, vander Waal I. Surgical treatment of squamous cell carcinoma of the lower lip: evaluation of long-term results and prognostic factors-a retrospecttive analysis of 184 patients. J Oral Maxillofac Surg 1998;56:814-20. [CrossRef][PubMed] 


\title{
PETOGODIŠNJE ISKUSTVO U HIRURŠKOM LEČENJU KARCINOMA USNE
}

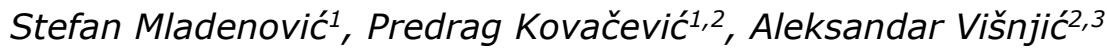 \\ ${ }^{1}$ Klinika za plastičnu i rekonstruktivnu hirurgiju, Klinički centar Niš, Niš, Srbija \\ Univerzitet u Nišu, Medicinski fakultet, Niš, Srbija \\ ${ }^{3}$ Institut za javno zdravlje Niš, Niš, Srbija \\ Kontakt: Stefan Mladenović \\ Bul. dr Zorana Đinđića 48, 18000 Niš, Srbija \\ E-mail: fahste1990@yahoo.com
}

Karcinom usne je čest malignitet i čini $25 \%$ karcinoma usne duplje i oko $12 \%$ svih tumora glave i vrata. Najčešći karcinomi usne su skvamocelularni karcinom (SCC), bazocelularni karcinom (BCC) i bazoskvamocelularni karcinom (BSC). Cilj istraživanja je opisivanje kliničkih karateristika tumora, hirurških tehnika i ishoda nakon operacije karcinoma usne u univerzitetskom kliničkom centru u Nišu. Sproveli smo retrospektivnu studiju, koja je obuhvatila bolesnike hirurški lečene od karcinoma usne na Klinici za plastičnu i rekonstruktivnu hirurgiju Kliničkog centra Niš, u periodu od 5 godina. U istraživanje je uključeno ukupno 32 bolesnika sa karcinomom usne. Devetnaest (59\%) bolesnika bilo je muškog pola, a $13(41 \%)$ ženkog. Bilo je 20 bolesnika sa SCC, 11 sa BCC i bio je jedan bolesnik sa BSC. Prosečna starost bolesnika bila je 73,44 godine (SD 9,95) u vreme prvog pregleda. Tumori su ekscidirani sa hirurškom marginom od najmanje $5 \mathrm{~mm}$. Hirurško lečenje zavisilo je od veličine tumora i njegove lokalizacije. Različite hirurške tehnike korišćene su za rekonstrukciju defekata usana nastalih nakon uklanjanja tumora. Trideset jedan posto bolesnika imao je postoperativne komplikacije. Tokom praćenja bolesnika, nije bilo recidiva tumora ili smrti povezanih sa tumorom. Kod bolesnika kod kojih je izvršena šira resekcija tkiva i izvedena složenija tehnika rekonstrukcije, veća je mogućnost pojave ranih postoperativnih komplikacija.

Acta Medica Medianae 2020;59(3):68-72.

Ključne reči: karcinom usne, hirurško lečenje, rekonsrukicja, komplikacije 